\title{
SPATIAL DISTRIBUTION OF CEMENTITE PARTICLES IN Fe-0.67\% C STEEL
}

\author{
ROZMIESZCZENIE CZĄSTEK CEMENTYTU W STALI Fe-0.67\% C
}

\begin{abstract}
The particles arrangement in material space is represented by point field determined by the particle reference points, i.e., particle centers which can be described by the pair-correlation function (PCF) $g_{3}(r) ; r$ - correlation distance. Information about $g_{3}(r)$ can be obtained by stereological method based on the PCF $g_{2}(r)$, which describes the point field on the planar section determined by the centers of particle planar sections. In this paper the arrangement of cementite $\left(\mathrm{Fe}_{3} \mathrm{C}\right)$ particles during coarsening in $\mathrm{Fe}-0,67 \% \mathrm{C}$ steel at $715^{\circ} \mathrm{C}$ in a form of two materials $(\mathrm{A}, \mathrm{B})$ of different microstructure of the coarse spheroidite (with different matrix grain size and particles position) was investigated. In material A, the particles are mainly at grain (subgrain) boundaries of fine-grained matrix. In material B, particles are mainly inside grains of coarse-grained ferrite. For material A, the empirical PCF $g_{2}(r)$ for a long time of coarsening (600 hours) is shifted towards larger $r$ and is more flat near the $g_{2}(r)=1$ than the one of coarsening for 50 hours. For material B, the $g_{2}(r)$ for both annealing times are not significantly different. This is consistent with the results of the probability density function $f_{2}(d)$ analysis for diameter $(d)$ of the particle sections. Obtained PCF $g_{2}(r)$ are similar to the PCF $g_{2}(r)$ for planar section of the Stienen model. This means that for both type of microstructures the PCF $-g_{3}(r)=1$, i.e., particles are distributed randomly in space and the sizes of the neighboring particles are correlated with each other.
\end{abstract}

Keywords: particle coarsening, particles arrangement, pair-correlation function, spatial distribution, stereology

Rozmieszczenie cząstek w przestrzeni reprezentuje pole punktowe wyznaczone przez punkty - środki cząstek, funkcja PCF $g_{3}(r)\left(r\right.$-odległość korelacji) jest jego charakterystyką. Informacje o PCF $g_{3}(r)$ można otrzymać na drodze stereologicznej, na podstawie funkcji PCF $g_{2}(r)$, która opisuje pole punktowe na płaszczyźnie (zgładzie), wyznaczone przez punkty - środki przekrojów cząstek. W niniejszej pracy badano rozmieszczenie cząstek cementytu $\left(\mathrm{Fe}_{3} \mathrm{C}\right)$ podczas koagulacji (przy temperaturze $715^{\circ} \mathrm{C}$ ), w stali $\mathrm{Fe}-0,67 \% \mathrm{C}$, w postaci dwóch materiałów (A, B) różniących się mikrostrukturą (wielkością ziarna osnowy i rozmieszczeniem cząstek). W materiale A, cząstki cementytu są głównie na granicach ziarn (podziarn) drobnoziarnistego ferrytu. W materiale B, cząstki są przeważnie wewnątrz ziarn gruboziarnistego ferrytu. Dla materiału A, empiryczna PCF $g_{2}(r)$ dla długiego czasu koagulacji (600 godzin) jest przesunięta w kierunku większych wartości $r$ i jest bardziej płaska przy $g_{2}(r)=1$ niż dla 50 godzin koagulacji. Dla materiału $\mathrm{B}$, funkcje $g_{2}(r)$ dla obu czasów wyżarzania nie różnią się znacznie. Jest to zgodne $\mathrm{z}$ wynikami analizy funkcji gęstości prawdopodobieństwa $f_{2}(d)$ średnic $(d)$ przekrojów cząstek. Otrzymane PCF $g_{2}(r)$ są podobne do PCF $g_{2}(r)$ dla modelu Stienena. Oznacza to, że dla obu rodzajów mikrostruktury PCF $-g_{3}(r)=1$, tj. cząstki są losowo rozmieszczone w przestrzeni, a rozmiary sąsiednich cząstek są ze sobą skorelowane.

\section{Introduction}

In the microstructure of a two phase $(\alpha, \beta)$ material the $\beta$ phase may appear as a disperse form i.e. a form of small particles which are randomly distributed in the matrix $\alpha$. In case of a polycrystalline matrix $\alpha$, the $\beta$ phase particles are distributed inside the $\alpha$ grains as well as on the grain boundaries. At sufficiently high temperatures the particle coarsening process (Ostwald ripening) take place, i.e., the bigger particles grow at the expense of the smaller ones [1]. During coarsening volume fraction of $\beta$ phase is constant, the particle density decreases and the mean particle size increases. In addition particle size distribution and their spatial distribution change too.
The aim of the present work is investigation of spatial distribution of cementite $\mathrm{Fe}_{3} \mathrm{C}\left(\beta=\mathrm{Fe}_{3} \mathrm{C}\right)$ particles during coarsening for two different microstructures of the coarse spheroidite in a medium carbon steel. In the first case particles were situated mainly at the ferrite matrix grain boundaries, in second case particles were situated mainly in matrix grains [2].

\section{Quantitative microstructure analysis}

\section{Spatial microstructure (3D)}

The basic quantitative characteristics of the $\beta$ phase in spatial microstructure (3D) are: volume fraction $V_{V}$, particle 
density $N_{V}, f_{3}(D)$ function (particle size $(D)$ distribution in form of probability density (PD)) and the pair correlation function PCF $g_{3}(r)$ (describing the spatial distribution of points the geometric centers of the particles).

\section{Pair-correlation function (PCF) [3]}

Let $\varphi$ be the point field specified by centers of the $\beta$ phase particles. Point density of the $\varphi$ is $N_{V}$. Let $T$ be a sphere of an infinitesimal volume $d V ; p$ is the probability that $T$ contains one point of the field $\varphi\left(p=N_{V} d V\right)$. Let $T_{12}(r)$ be a pair of disjoint spheres with infinitesimal volumes $d V$ and distance $r$ of their centers. For a given $r, p(r)$ is the probability that in both spheres there is each a point of the $\varphi$. The PCF $g_{3}(r)$ function, has a form:

$$
g_{3}(r)=\frac{p(r)}{p^{2}}
$$

The function $g_{3}(r)$ describes the "interaction" between points of field $\varphi$. $\left(g_{3}(r)=1\right.$ means that there are no interactions, $g_{3}(r)>1$ - indicates attractions and $g_{3}(r)<1-$ repulsion of the points.

\section{Planar microstructure (2D)}

A microscopic studies of metallic materials are carried out on planar sections of material, containing the planar microstructure (2D). The basic quantitative characteristics of the particle sections of the planar microstructure are: area fraction $A_{A}$, particle density $N_{A}, f_{2}(d)$ particles section size $(d)$ distribution function (in form of PD) and PCF $g_{2}(r)$ function describing the planar distribution of points - the geometric centers of the particle sections. (The definition of the $g_{2}(r)$ function is analogical to the definition of the $g_{3}(r)$ function.)

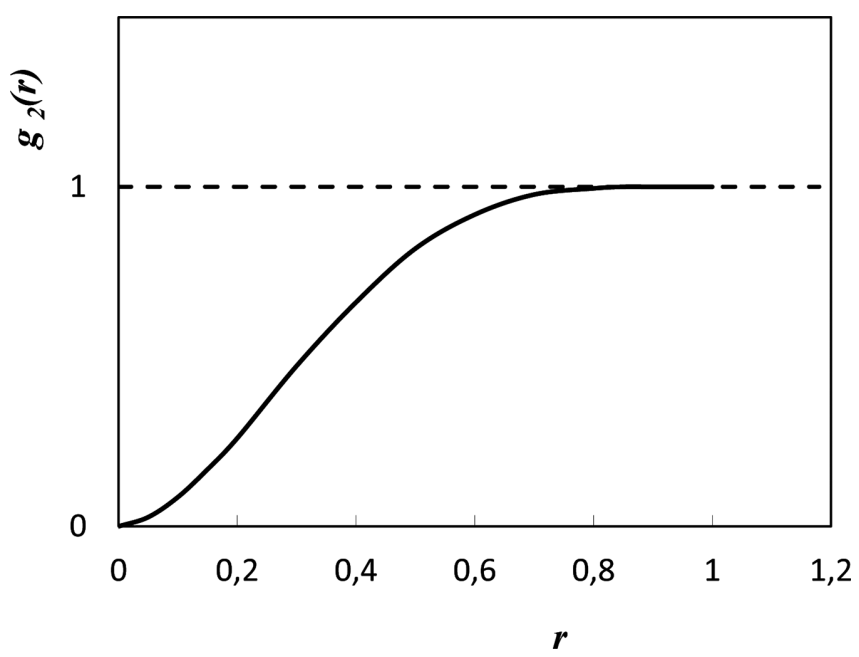

Fig. 1. PCF $g_{2}(r)$ function for planar section of the Stienen model

\section{Stereology}

Typical stereological measurement methods of parameters $V_{V}, N_{V}$ and $f_{3}(D)$ function are well known [1]. The stereology of particle distribution was investigated by Stoyan et al. [4]; the given equations of the functions $g_{2}(r)$ and $g_{3}(r)$ has a complicated mathematical form and although it does not follow a specific stereological measurement method it is practically useful because it allows to calculate the $g_{2}(r)$ function on basis of the given function $g_{3}(r)$ for model systems of spheres. In studies of the $\mathrm{Fe}_{3} \mathrm{C}$ carbide disperse phase coarsening in steel the Stienen model $[3,5]$ was used.

\section{Particles arrangement during coarsening}

During coarsening process the bigger particles grow at the expense of the smaller ones, as a result, the smallest particles disappear ( $N_{V}$ decreases). It means there is a dependence between the point field $\varphi$ of particle centers (i.e. spatial distribution of particles) and the coarsening process.

\section{Experimental}

\subsection{Materials and heat treatment}

For investigation $\mathrm{Fe}-0,67 \% \mathrm{C}$ steel was used. The steel composition is given in TABLE 1.

TABLE 1

Chemical composition of $\mathrm{Fe}-0,67 \% \mathrm{C}$ steel

\begin{tabular}{|c|c|c|c|c|c|c|c|c|c|}
\hline \hline $\begin{array}{c}\text { Element } \\
\text { content } \\
\text { [wt. \% }\end{array}$ & $\mathrm{C}$ & $\mathrm{Mn}$ & $\mathrm{Si}$ & $\mathrm{P}$ & $\mathrm{S}$ & $\mathrm{Cr}$ & $\mathrm{Ni}$ & $\mathrm{Cu}$ & $\mathrm{Fe}$ \\
\cline { 2 - 8 } & 0,27 & 0,20 & 0,011 & 0,016 & 0,07 & 0,04 & 0,07 & Balance \\
\hline
\end{tabular}

Preliminary heat treatment was carried out to produce a coarse spheroidite (i.e, coarse cementite particles in ferrite matrix):

- austenitizing at $900^{\circ} \mathrm{C}$ for 2 hours,

- quenching into $5 \%$ caustic soda solution,

- tempering at $700^{\circ} \mathrm{C}$ for 150 hours in vacuum $\left(10^{-2} \mathrm{Tr}\right)$.

A part of the material was cold rolled with $10 \%$ deformation. Then, the both materials (deformed or not) were annealed at $700^{\circ} \mathrm{C}$ for 5 hours in vacuum. Annealed material was the starting material for investigation of cementite coarsening process. Material which was only annealed was marked by A and material which was deformed and annealed was marked by B.

From both materials A and B specimens were taken for cementite coarsening. The specimens were annealed at $715^{\circ} \mathrm{C}$ for 50 and 600 hours in vacuum $\left(\sim 10^{-2} \mathrm{Tr}\right)$. The cementite particles coarsening was analysed metallographically by light microscopy.

\subsection{Qualitative metallography}

Planar surface of specimens was polished mechanically and etched: (i) in picral (for contrasting the $\mathrm{Fe}_{3} \mathrm{C}-$ ferrite interface boundaries and (ii) in nital (for revealing ferrite grain boundaries); (iii) in boiling alkaline sodium picrate (for colouring cementite particles - to distinguish them from ferrite grains).

The microstructure of A material after annealing is shown in Fig. 2. Most particles are at grain boundaries of the in situ recrystallized fine-grained matrix. During annealing particle growth (coarsening) and matrix grain growth take place. One can see that during annealing the microstructure morphology is in principle preserved $[2,7]$. 
The microstructure of B material after annealing is shown in Fig. 3. In the initial state (Fig. 3a), most particles are in grains of the discontinuous recrystallized coarse-grained matrix. Particles inside grains are mainly of a circular shape. Particles at grain boundaries are slightly larger; isolated particles are convex. During annealing particle growth (coarsening) take place which is less pronounced than in case of material A. The matrix grain size is only little changed. The microstructure morphology is preserved $[2,7]$.
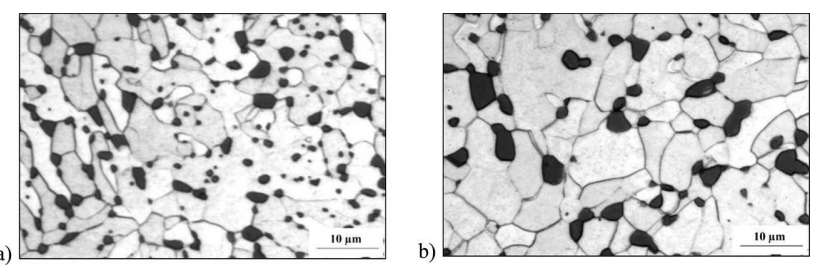

Fig. 2. Microstructures of material $\mathrm{A}$ after annealing at $715^{\circ} \mathrm{C}$ during: a) $50 \mathrm{~h}, \mathrm{~b}) 600 \mathrm{~h}$
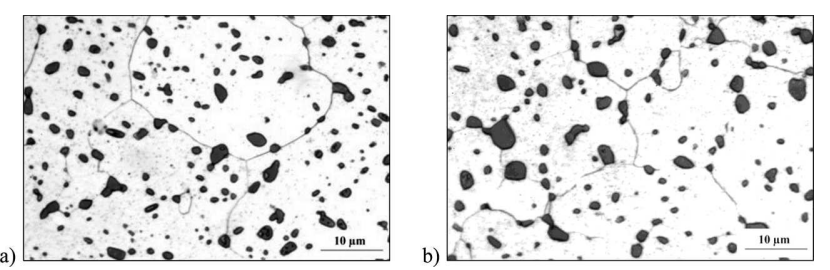

Fig. 3. Microstructures of material $\mathrm{B}$ after annealing at $715^{\circ} \mathrm{C}$ during: a) $50 \mathrm{~h}, \mathrm{~b}) 600 \mathrm{~h}$

\subsection{Quantitative metallography}

For specimens etched with picral a series of $N W$ photographic images of the microstructure was performed, with a total magnification of $2700 \times$. On the photographs in $40 \times 60 \mu \mathrm{m}$ test rectangle $W$ the parameters $A_{A}, N_{A}$ and the coordinates of points - the centers of gravity of the cementite particles, which form the point field $\varphi$, were determined by computer image analysis methods with Met-Ilo software [8].

For the $\varphi$ field in the test area $W$ of observation, the empirical PCF $g_{2}(r)$ was determined by an edge corrected kernel estimator. Let $x_{i}(i=1,2, \ldots, N)$ denote points of the $\varphi$ field in $W$. The kernel estimator for $g_{2}(r)$ is of a form [9]

$$
g_{2}(r)=\frac{1}{2 \pi N_{A}^{2}} \sum_{i=1}^{N} \sum_{(j \neq i)=1}^{N} \frac{f_{\delta}\left(r-r_{i j}\right)}{r_{i j} A\left(W_{x_{i}} \cap W_{x_{j}}\right)},
$$

the summation goes over all points $x_{i}$ in $W ; r_{i j}$ is the distance between points $x_{i} x_{j} ; W_{x i}\left(W_{x j}\right)$ is the $W$ translated by $x_{i}\left(x_{j}\right)$. $A(B)$ is the area of set $B$ and $f_{\delta}(t)$ is the kernel function. The so-called Epanechnikov kernel function is as follows:

$$
f_{\delta}(t)=\left\{\begin{array}{lc}
\frac{3}{4 \delta \sqrt{5}}\left(1-\frac{t^{2}}{5 \delta^{2}}\right), & |t|<\delta \sqrt{5} \\
0, & \text { otherwise }
\end{array}\right.
$$

where $\delta$ is a band-width parameter $\left(\delta \approx 1 / \sqrt{ } N_{A}\right.$, [9].

For a given $\varphi$ field, the empirical PCF $g_{2}(r)$ is the mean of $N W$ by Eq. (2) estimated PCFs.
Empirical function $f_{2}(d)$ was determined for the cementite particles in the circular approximation [10]. Stereological studies have shown that the empirical function $f_{2}(d)$ can be approximated by PD function of the Weibull distribution, i.e.,

$$
f_{2}(d)=n a d^{n-1} \exp \left(-a d^{n}\right)
$$

for

$$
a=\left[\frac{\Gamma\left(\frac{1}{n}+1\right)}{\langle d\rangle}\right]^{n},
$$

where $\langle d\rangle$ - mean cementite particles diameter,

$$
\begin{aligned}
& n \text { - parameter }(n>1), \\
& \Gamma \text { - Euler gamma function. }
\end{aligned}
$$

\section{Results, discussion and conclusions}

The empirical parameters $A_{A}, N_{A},\langle d\rangle$, of the materials A and $\mathrm{B}$ microstructure, the number of test areas $(N W)$ and the total particle number $(N T)$ in $N W$ areas for the PCFs $g_{2}(r)$ are given in TABLE 2.

TABLE 2

The empirical parameters of the materials A and B microstructure and measurement conditions

\begin{tabular}{|c|c|c|c|c|c|c|}
\hline \hline $\begin{array}{c}\text { Mate- } \\
\text { rial }\end{array}$ & $\begin{array}{c}\text { Anne- } \\
\text { aling } \\
\text { time, } \mathrm{h}\end{array}$ & $\begin{array}{c}\text { Area } \\
\text { fraction, } \\
A_{A}\end{array}$ & $\begin{array}{c}\text { Particle } \\
\text { density, } \\
N_{A} \times 10^{-4}, \\
\mathrm{~mm}^{-2}\end{array}$ & $\begin{array}{c}\text { Mean } \\
\text { diameter, } \\
\langle d\rangle \times 10^{3}, \\
\mathrm{~mm}\end{array}$ & $\begin{array}{c}\text { Number } \\
\text { of test } \\
\text { areas, } \\
N W\end{array}$ & $\begin{array}{c}\text { Total } \\
\text { particle } \\
\text { number, } \\
N T\end{array}$ \\
\hline \multirow{2}{*}{$\mathrm{A}$} & 50 & 0,11 & 7,73 & 1,04 & 5 & 1027 \\
\cline { 2 - 7 } & 600 & 0,11 & 3,74 & 1,52 & 20 & 1778 \\
\hline \multirow{2}{*}{$\mathrm{B}$} & 50 & 0,11 & 8,90 & 0,99 & 10 & 2284 \\
\cline { 2 - 7 } & 600 & 0,10 & 6,92 & 1,01 & 12 & 2378 \\
\hline
\end{tabular}

TABLE 2 shows that the cementite coarsening process takes place at constant volume fraction $V_{V}\left(V_{V}=A_{A}\right)$, i.e., in accordance with conditions of the coarsening process [1]. With progress of coarsening the $2 \mathrm{D}$ particle density $N_{A}$ decreases and the average particle diameter increases at a rate dependent on the type of matrix microstructure. For material B particle coarsening occurs very slowly. A more detailed analysis covers particle size distribution and the PCF function.

\section{Particle size distribution}

Stereological studies of the Weibull distribution showed that for the obtained parameter $n(n=1,68 \div 1,81)$ the functions $f_{2}(d)$ and $f_{3}(D)$ are similar to each other (eg. for the Rayleigh distribution $\left.(n=2) f_{2}(d)=f_{3}(D)\right)$ [10]. With some unavoidable statistical scatter of experimental data the empirical function $f_{2}(d)$ and $f_{3}(D)$ are practically indistinguishable. For this reason, examination of particle size distribution was limited to the function $f_{2}(d)$ only.

Studies have shown that for material A the function $f_{2}(d)$ strongly depends on coarsening time while for material $\mathrm{B}$ - not. Empirical functions $f_{2}(d)$ (represented by the PD of Weibull distribution) for materials $\mathrm{A}$ and $\mathrm{B}$ after 600 hours of coarsening are shown in Fig. 4. These functions differ significantly each other, flattened graph for the material $\mathrm{A}$ is consistent with higher cementite coarsening rate. 


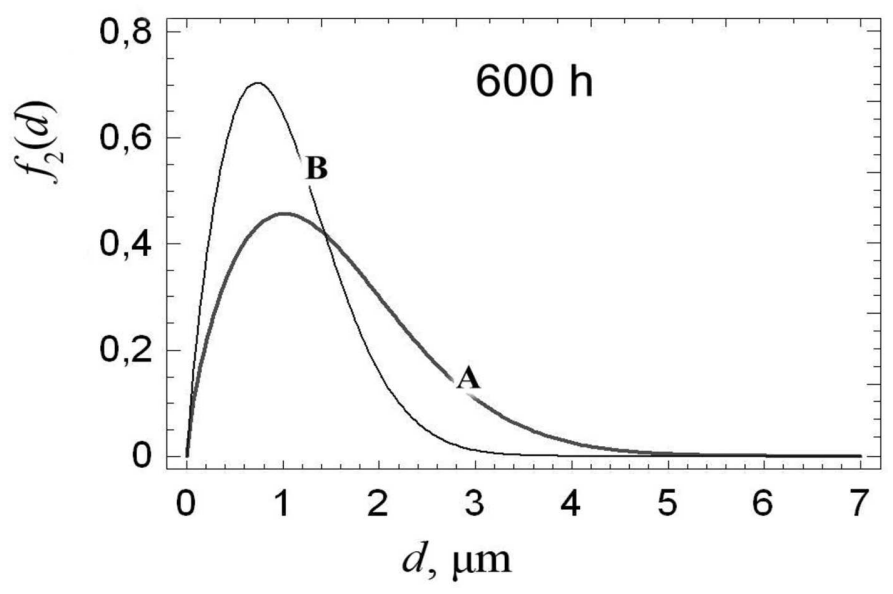

Fig. 4. PD function of the Weibull distribution, $f_{2}(d)$ for materials A and $\mathrm{B}$ after coarsening for 600 hours

\section{The PCF Function}

Studies have shown that empirical function $g_{2}(r)$ depends on the coarsening time and microstructure of the material matrix. For material A empirical function $g_{2}(r)$ strongly depends on the coarsening time while for material B - not.

The empirical functions $g_{2}(r)$ after 600 hours of coarsening are given in Fig. 5. For material A function $g_{2}(r)$ is more shifted to the right, it should be associated with higher cementite coarsening rate. The empirical functions $g_{2}(r)$ are similar in shape, but there are statistically significant differences. For smaller values of $r$, the functions are increasing and reach values close to 1 . Next, for the material $\mathrm{A}, g_{2}(r) \approx 1$ and for the material $\mathrm{B}$, after reaching value $1, g_{2}(r)$ is slightly greater than 1 (weak attraction between points) and then approaches 1 , (i.e., $g_{2}(r) \approx 1$ ). It is important to notice that for the empirical PCFs of material B the observed relation $g_{2}(r)>1$ is statistically significant.The local difference in shape of the empirical $g_{2}(r)$ functions for A and B is probably due to the influence of matrix microstructure on the arrangement of particles, Fig. 2 and Fig. 3.

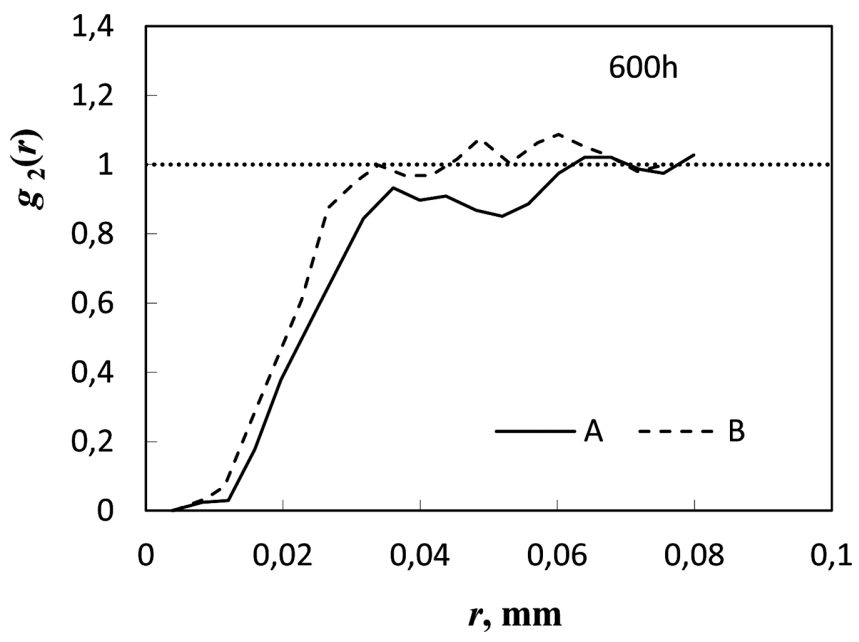

Fig. 5. PCF $g_{2}(r)$ for materials A and B after coarsening for 600 hours
Generally, the shape of the empirical function $g_{2}(r)$ is similar to the corresponding function for point field of circle centers on planar section of the Stienen model (Fig. 1). In the first approximation it can be assumed that cementite particles in the examined materials can be described by Stienen model. This means that the particles are distributed randomly in space and the neighbour particle diameters are statistically dependent on each other. For the material B deviation from the Stienen model is greater. Obtained results for material A confirm the results of Stoyan and Wiencek [3, 5].

It should be noted that after 600 hours of coarsening the difference between the empirical functions $g_{2}(r)$ (Fig. 5) is smaller than that between the empirical functions $f_{2}(d)$ (Fig. 4). The function $f_{2}(d)$ is more sensitive to coarsening than the PCF function $g_{2}(r)$. However, the $g_{2}(r)$ function notices the influence of the matrix microstructure on the arrangement of particles.

\section{Acknowledgements}

The financial support from the Polish Ministry of Science and Higher Education, contract AGH no.10.10.110.082 is gratefully acknowledged.

\section{REFERENCES}

[1] J. R y s, K. W i e n c e k, Coarsening of phases in alloys (in Polish), Wyd. Slask, Katowice 1979.

[2] P. M a t u s i e w i c z, K. W i e n c e k, Archives of Metallurgy and Materials 55, 231-238 (2010).

[3] D. S t o y a n, K. W i e n c e k, Materials Characterization 26, 167-176 (1991).

[4] D. Stoya n, L. vo n Wolfersdorf, J. Ohser, Math. Nachr. 146, 33-46 (1990).

[5] K. W i e n c e k, Steel Research 67, 419-422 (1996).

[6] D. S t o y a n, Statistics 21, 131-136 (1990).

[7] P. Matusiewicz, W. Ratuszek, A. Zi e li ín k a - L i p i e c, Archives of Metallurgy and Materials 56, 63-69 (2011).

[8] J. S z a 1 a, Informatyka w Technologii Materiałów 3, 41-57 (2003).

[9] D. S t o y a n, W.S. K e n d a 11, J. M e c k e, Stochastic geometry and its applications, J. Willey, Chichester 1995.

[10] P. M a t u si e w i c z, Relationship between ferrite recrystallization and coarsening of dispersed carbide phase in Fe- $0.67 \%$ C steel (in Polish), PhD thesis, AGH, Krakow (2009). 